\title{
Fællesskab eller individualitet - om forskning og undervisning i et interdisciplinært universitetsmiljø
}

\author{
Anne Jensen, ph.d., lektor, Institut for Kulturvidenskaber, Syddansk Universitet. \\ Rie Troelsen, ph.d., lektor, Institut for Kulturvidenskaber, Syddansk Universitet. \\ Lilli Zeuner, ph.d., lektor, Institut for Kulturvidenskaber, Syddansk Universitet.
}

\section{Reviewet artikel}

Der er en tiltagende satsning på interdisciplinære undervisningsformer $i$ forskellige dele af det danske uddannelsessystem. På universiteterne indføres der $i$ stigende grad interdisciplinære studier, hoor forskellige fagomräder indgår i det samme studieforløb. Spørgsmålet er, hvad konsekvenserne af denne interdisciplinære tænkning i forskning og undervisning er. Artiklen præsenterer resultatet af analyser af interview med 16 videnskabeligt ansatte med henblik på at afdxkke deres holdninger, handlinger og folelser $i$ relation til interdisciplinær forskning og undervisning. Det viser sig, at de videnskabelige medarbejdere, som arbejder alene om at sammentænke fag, oplever en stor glæde ved såvel undervisning som forskning, og at de sætter fokus på den enkelte studerendes personlige udvikling, mens de medarbejdere, der skaber interdisciplinariteten sammen med folk fra andre fag, føler sig mere splittede og har mindre fokus på den enkelte studerendes udvikling. Resultaterne tyder på, at man især på interdisciplinxre uddannelser skal gøre særlig meget ud af at give underviserne mulighed for og ressourcer til at sammentænke undervisning - og måske endda til at følge og følge op på hinandens undervisning.

\section{Introduktion}

Multidisciplinær, paradisciplinær, transdisciplinær eller interdisciplinær? Forskningslitteraturen har ikke blot forsøgt at definere, hvad der på dansk ofte kaldes tværfaglighed, men har også set på hvilke konsekvenser, definitionerne har for den praksis, man finder inden for både forskning og undervisning. Forskningen beskæftiger sig i store træk med dels en normativ tilgang, dvs. at den interdisciplinære tilgang giver de bedste resultater (Cook-Sather, 2007; Fry, 2001; Youngblood, 2007), dels en analytisk tilgang, som søger at udvikle forskellige modeller for, hvorledes den interdisciplinære tænkning kan foregå (Kline, 1995; Finkenthal, 2001; Moran, 
2002) og endelig en empirisk tilgang, hvor den konkrete udmøntning af interdisciplinaritet gøres til genstand for undersøgelser (Francks et al., 2007; Trigwell, 2005; Lacutta, 2002; Nowotny et al., 2001; Brew, 2008). I denne artikel skriver vi os ind i den empiriske tradition og fokuserer på, hvordan det interdisciplinære arbejde praktiseres i forskning og undervisning.

\section{Definition, forskningsspørgsmål og metode}

Vi har i vores undersøgelse anvendt begrebet interdisciplinaritet og forstår det bredt som det arbejde, der forbinder, skaber dialog og baner vejen for en gensidig udvikling mellem disciplinerne (Camic og Joas, 2004). Formålet med vores undersøgelse er at finde ud af, hvordan en gruppe forskere $\mathrm{i}$ et interdisciplinært fagmiljø arbejder interdisciplinært i forskning og undervisning.

Undersøgelsen bygger på semistrukturerede interview af 1-11/2 times varighed med fastansatte VIP'er på et dansk universitetsinstitut, i alt 16 interview. De interviewede repræsenterer fag fra de samfundsvidenskabelige, humanistiske og naturvidenskabelige områder men er ansat på samme institut.

Fokus i interviewene har været på de kriterier, som informanterne tager i anvendelse i afklaringen af det gode arbejde i forskning og undervisning. Analytisk vil vi benytte os af den idealtypetænkning, som Max Weber (1904/49) har udviklet. Den indebærer, at man skaber en teoribaseret begrebsramme gennem en fremhævelse af bestemte elementer af virkeligheden for derefter at undersøge i hvilken grad, denne konstruktion kan genfindes i den empiriske virkelighed. I vores analyse vil vi især fremhæve den sociale interaktion i det interdisciplinære arbejde og dens sammenhæng med livsverdensdimensioner, herunder holdninger, handlinger og personlighed. Den sociale interaktion forstår vi som den måde, samarbejdet foregår (eller ikke foregår) på i et interdisciplinært universitetsmiljø, idet et sådant typisk vil bestå af videnskabeligt personale (VIP) repræsenterende forskellige fagligheder. Man kan forestille sig to modeller for det interdisciplinære arbejde: En VIP'er kan tilegne sig viden fra flere forskellige faglige områder og dermed udnytte flere former for indsigter omkring et givet emne, eller flere VIP'er med hver deres faglige baggrund kan gå sammen om det fælles akademiske arbejde således, at de hver især bidrager med deres specielle viden. Spørgsmålet er, hvad disse forskellige tilgange i kombination med livsverdensdimensioner betyder for, hvordan forskning og undervisning forstås, gøres og føles. 


\section{Den sociale dimension ved interdisciplinær forskning}

Forskning er grundlæggende set en kulturel aktivitet, som er underlagt de samme mekanismer som andre kulturelle aktiviteter. Den skabes af kulturelle aktører, som kan være påvirkede af den eksisterende kulturs indbyrdes relationer (Archer, 1988/96), af aktørernes indre habitus (Bourdieu, 1979/84) eller af den sociale kontekst, de indgår i (Habermas, 1984-87/91). I denne artikel har vi valgt at tage udgangspunkt i den sociale kontekst og forskerens holdninger, handlinger og personlighed med henblik på at undersøge, hvordan interdisciplinaritet praktiseres i forskningsarbejdet. I forbindelse med synet på forskning har vi spurgt til interviewpersonernes opfattelse af sandhed, brug af forskningsmetoder og følelsesmæssige oplevelse (Bloch, 2007). Sammenfatningen af de interviewedes svar er illustreret i figur 1.

\begin{tabular}{|c|c|c|c|}
\hline $\begin{array}{l}\text { Den sociale inter- } \\
\text { aktion i det interdi- } \\
\text { sciplinare forsk- } \\
\text { ningsarbejde }\end{array}$ & $\begin{array}{l}\text { Holdninger: } \\
\text { Opfattelse af } \\
\text { sandhed }\end{array}$ & $\begin{array}{l}\text { Handlinger: } \\
\text { Brug af forskningsme- } \\
\text { toder }\end{array}$ & $\begin{array}{l}\text { Personlighed: } \\
\text { Følelser ved det } \\
\text { interdisciplinaere } \\
\text { forskningsarbejde }\end{array}$ \\
\hline $\begin{array}{l}\text { Arbejder alene } \\
\text { med at sammen- } \\
\text { taenke flere disci- } \\
\text { pliner }\end{array}$ & $\begin{array}{l}\text { Afhænger af } \\
\text { individuel tilgang } \\
\text { Afhænger af } \\
\text { kildernes } \\
\text { brugbarhed }\end{array}$ & $\begin{array}{l}\text { Fokuseret metodevalg } \\
\text { Inddrager supplerende } \\
\text { metoder }\end{array}$ & $\begin{array}{l}\text { Glæde over } \\
\text { muligheder og } \\
\text { udfordringer } \\
\text { Glæde over positiv } \\
\text { respons }\end{array}$ \\
\hline $\begin{array}{l}\text { Arbejder sammen } \\
\text { med andre med at } \\
\text { sammentænke } \\
\text { flere discipliner }\end{array}$ & $\begin{array}{l}\text { Afhænger af } \\
\text { forhandlinger } \\
\text { Afhænger af } \\
\text { empiri og logik }\end{array}$ & $\begin{array}{l}\text { Pragmatisme i metode- } \\
\text { valget }\end{array}$ & $\begin{array}{l}\text { Glæde men også } \\
\text { frustrationer } \\
\text { Glæde men også en } \\
\text { følelse af at være } \\
\text { splittet }\end{array}$ \\
\hline
\end{tabular}

Figur 1. Idealtyper for den sociale interaktions betydning for forskernes relation til den interdisciplinære forskning.

Alle de interviewede forskere erklærer, at de i deres forskning arbejder interdisciplinært. Dette udgangspunkt betyder, at alle må forholde sig refleksivt til spørgsmålet om sandhed, dvs. hvilke kriterier de stiller op for vidensudvikling. Idéen om, hvad sandhed er, udfordres af arbejdet med at bringe flere discipliner med dertil hørende sandhedskriterier i dialog. Spørgsmålet er nu, hvilke kriterier for sandhed forskerne tager i anvendelse.

Ser vi først på de forskere, som primært arbejder alene om at sammentænke flere fag, viser der sig en tendens til, at deres individuelle tilgang får en væsentlig betydning: "Sandheden skal forstås ikke absolut, men hermeneutisk, og i den hermeneutiske verden er der mange løse ender" og "Sandheden bliver dynamisk". Man kan også forholde sig pragmatisk til sandheden og se den som "the best account so far". Gør 
man det, har man ofte en mere empirisk orienteret forståelse af sandhed: "Der må være et kildefast grundlag".

Omvendt er der blandt de forskere, som samarbejder med forskere fra andre discipliner end deres egen, en tendens til, at forhandlingen spiller en afgørende rolle i vurderingen af, hvad der er sandt: "I forskningen sker der en forhandlet meningsdannelse". "Sandheden er relativ og afhænger af, hvilke ressourcer man har til rådighed. Tid og penge sætter grænser og rammer". Sandheden kan også være etisk begrundet: "Der er hensynet til mennesker og hensynet til sagen". Inden for denne gruppe ser vi dog også en mere erfaringsorienteret tilgang: "Der skal være tilstrækkelig empirisk kontakt". Og der må være "logisk konsistens".

Ser vi på de to gruppers opfattelse af, hvilke metoder der giver de mest troværdige forskningsresultater, er det karakteristisk, at de forskere, som arbejder alene med at syntetisere elementer fra forskellige fag, tager udgangspunkt i metoder fra deres oprindelige fag. Litteraturforskeren er primært inspireret af litteraturvidenskaben: "Forskeren indsamler empiri og fortolker tekster. Er der noget mellem linjerne?". Andre inden for denne kategori satser på at udvikle metoder, som er begrundet i forskellige discipliner. Metoderne er udviklet eksperimentelt og er derfor relativt fokuserede. Men der er også åbenhed i relation til andre metoder.

Ser vi på de forskere, som arbejder sammen med forskere fra andre discipliner, så viser der sig en større variation i metodevalget. En forsker udtaler: "Jeg foretager en blanding af metoder fra sociologien, afsætningsøkonomi, fortolkende videnskaber, psykologi. Jeg hugger med næb og klør". En anden siger: "Jeg laver metodetriangulering med kvantitative og kvalitative metoder." Andre inden for denne gruppe er mere pragmatiske: Man tager de metoder, som synes mest anvendelige.

Der er desuden følelsesmæssige forskelle mellem de to grupper. Når man spørger til den generelle vurdering af det at forske, så giver forskere fra den gruppe, der arbejder alene, udtryk for stor glæde ved det interdisciplinære arbejde: "Drivkraften i forskningen er nysgerrighed ved forklaringerne. Sammenstødene mellem fagene tvinger en til at stille spørgsmål - tænke nye problematikker - være kreativ."

De forskere, som arbejder sammen om den interdisciplinære tilgang, er mere nuancerede i deres vurdering. Der kan fx være spørgsmålet om, hvorvidt man i tilstrækkelig grad kommer i dybden. "Man bliver en halvstuderet røver. Man har et underskud uanset, hvilken vej man går". Der udtrykkes dog også begejstring for det interdisciplinære arbejde: "Det bliver mere gennemtænkt. Der sker et dialektisk udviklingsarbejde, hvor man kommer tæt på kolleger". Mange inden for denne gruppe 
udtrykker en glæde ved at inddrage forskellige fag men også en følelse af at blive splittet.

Meget tyder altså på, at det interdisciplinære forskningsarbejde er mere enkelt, når en forsker arbejder ud fra sin egen disciplin og sine egne metoder og supplerer dette med elementer fra andre discipliner. Det er nemmere at finde en personlig synsvinkel, mere enkelt at finde eller udvikle metoder, og det giver tilsyneladende en glæde at kunne søge viden i alle typer af discipliner. Omvendt må den gruppe af forskere, som arbejder sammen med andre forskere, opleve, at der skal flere forhandlinger til for at nå frem til en forståelse af sandheden, at der kan arbejdes med mange typer af metoder, og at arbejdet bliver præget ikke bare af en større gennemtænkning af temaerne men også af en følelse af, at man kommer i underskud eller undergår en indre splittelse.

\section{Den sociale dimension $\mathrm{i}$ undervisningen}

Også undervisningen $\mathrm{i}$ et interdisciplinært miljø har en social dimension. De BA-, kandidat- og masteruddannelser, som bliver udbudt ved det valgte institut, er i udgangspunktet interdisciplinære, dvs. de består dels af en række undervisningsfag, som i deres grundkerne stammer fra enkeltdiscipliner, og dels af en række brede undervisningsfag, som har til formål at introducere, danne overblik over eller samle op på det interdisciplinære felt. Underviserne skal derfor ikke alene samarbejde om at skabe sammenhæng og dialog mellem de forskellige undervisningsfag men i mange tilfælde også inden for de enkelte undervisningsfag alt efter hvor bredt, disses emnefelter er defineret.

Da et egentligt samarbejde omkring undervisning $\mathrm{i}$ form af eksempelvis team teaching sjældent er muligt af tidsmæssige og økonomiske årsager, er undervisningen på instituttet organiseret ud fra to principper: Enten har én underviser ansvaret for et helt fag og optræder derfor ved hver undervisningsgang, eller en række medarbejdere optræder på ét fag typisk med én fagansvarlig, som så at sige hyrer de forskellige undervisere til at forestå enkelte undervisningsgange i faget. Disse forskellige organiseringsprincipper er dog blot to måder, hvorpå interdisciplinaritet kan fremtræde i undervisningssituationer (Armstrong, 1980).

Som med forskningstilgangen har vi også her taget udgangspunkt i den sociale kontekst og underviserens holdninger, handlinger og personlighed med henblik på at undersøge, hvordan interdisciplinaritet praktiseres i undervisningsarbejdet. I forbindelse med synet på undervisning har vi spurgt til interviewpersonernes opfattelse af læring, dvs. hvilke kriterier de stiller op for vidensudvikling hos deres studerende, brug af undervisningsmetoder og relationer i undervisningen. Sammenfatningen af de interviewedes svar er illustreret i figur 2. 


\begin{tabular}{|c|c|c|c|}
\hline $\begin{array}{l}\text { Den sociale interaktion i } \\
\text { det interdisciplinare } \\
\text { undervisningsarbejde }\end{array}$ & $\begin{array}{l}\text { Holdninger: } \\
\text { Opfattelse af ud- } \\
\text { vikling }\end{array}$ & $\begin{array}{l}\text { Handlinger: } \\
\text { Valg af undervis- } \\
\text { ningsmetode }\end{array}$ & $\begin{array}{l}\text { Personlighed: } \\
\text { Beskrivelse af } \\
\text { relationer }\end{array}$ \\
\hline $\begin{array}{l}\text { Underviser selv - vareta- } \\
\text { ger interdisciplinaritet } \\
\text { alene }\end{array}$ & $\begin{array}{l}\text { Fokus på den } \\
\text { studerendes selv- } \\
\text { udvikling } \\
\text { Undervisning } \\
\text { som mulighed for } \\
\text { selvindsigt }\end{array}$ & $\begin{array}{l}\text { Variation: } \\
\text { Fx dialogisk forelæs- } \\
\text { ning, gruppearbejde, } \\
\text { peer teaching, } \\
\text { studenteroplæg }\end{array}$ & $\begin{array}{l}\text { Underviseren } \\
\text { som rollemo- } \\
\text { del og mentor }\end{array}$ \\
\hline $\begin{array}{l}\text { Underviser sammen med } \\
\text { andre - varetager inter- } \\
\text { disciplinaritet i et samar- } \\
\text { bejde med andre }\end{array}$ & $\begin{array}{l}\text { Fokus på den } \\
\text { faglige udvikling } \\
\text { Undervisning som } \\
\text { en vej ind i faget - } \\
\text { og ud igen }\end{array}$ & $\begin{array}{l}\text { Variation: } \\
\text { Fx forelæsninger, } \\
\text { studenteraktiverende } \\
\text { former, refleksions- } \\
\text { skrivning, case- } \\
\text { undervisning }\end{array}$ & $\begin{array}{l}\text { Bliver ikke } \\
\text { nævnt }\end{array}$ \\
\hline
\end{tabular}

Figur 2. Idealtyper for den sociale interaktions betydning for underviseres relation til den interdisciplinære undervisning.

De interviewede erklærede alle, at de forskede interdisciplinært. Ligeledes er udgangspunktet for vores analyser af undervisningstilgangen, at alle interviewpersonerne underviser på uddannelser, der beskrives som interdisciplinære. Ligesom interviewpersonerne er refleksive omkring, hvilke sandhedskriterier de stiller for forskningen, viser de sig at være refleksive omkring deres holdninger til, hvilke kriterier der stilles op for de studerendes vidensudvikling.

Undervisere, som fungerer som eneste underviser på et fag og så at sige overskuer interdisciplinariteten selv, nævner primært den studerendes selvudvikling som målet for undervisningen: "Den studerende skal være medreflekterende på sin egen læreproces" og "undervisningen skal være horisontudvidende for den studerende". Underviserne inviterer den studerende indenfor i deres mangfoldige univers, hvor interdisciplinaritet handler om at anskue en problemstilling fra forskellige vinkler: "De studerendes skal [...] blive klar over, hvad de ser, og hvad de ikke ser ud fra det punkt, hvor de står" og "jeg prøver at pille de studerendes viden fra hinanden og lade dem komme i tvivl". Undervisningen skal give den studerende mulighed for og redskab til at se sig selv og sit fag udefra.

Den anden gruppe undervisere, der underviser sammen med andre på et fag og varetager interdisciplinariteten i samarbejde med andre, nævner primært faget og fagligheden som et mål for undervisningen: "Udvikling hos den studerende er kundskabsudvikling" og "den studerende skal tilegne sig et vidensfelt af teorier, begreber, metoder". Men den studerende skal ikke bare lære faget for fagets egen skyld. Underviserne lægger ligeledes vægt på, at den studerende bliver præsenteret for "noget, de kan bruge til noget" - altså på teoretisk videns relation til praksis. Nogle be- 
skriver denne todeling som 1. ordens og 2. ordens-viden, hvor 1. ordens-viden er selve forskningsformidlingen, og 2. ordens-viden er den studerendes eget arbejde med stoffet ("internaliseringsprocessen"). Undervisningen er en invitation ind i faget og en anvisning til overgangen mellem universitetsfag og praksisfag.

Forskellen mellem de to grupper af undervisere viser sig som en forskel på, i hvor høj grad den studerende antages at forandre sig som person i sit møde med faget eller i hvert fald, hvorvidt underviseren tænker dette ind i sin undervisning som kerneelement eller som biprodukt. Denne forskel kan meget vel tænkes at hænge sammen med "solo-undervisernes" bedre mulighed for at følge den studerendes læreproces gennem et tidsmæssigt længere og mere sammenhængende forløb i forhold til de undervisere, hvis undervisning - og kontakt med de studerende - er struktureret som perler på en snor.

Ser vi på, hvordan underviserne forsøger at gøre deres holdninger til handlinger, og føre deres intentioner om undervisningens mål ud i praksis, ser vi imidlertid ingen reel forskel. I gruppen af "solo-undervisere" benytter man sig som undervisningsmetode af klassiske forelæsninger med eksempler fra praksis, gruppearbejde, eller man lader de studerende undervise hinanden. Undervisere, der samarbejder med andre om undervisningen i et fag, vælger forelæsningsformen, studenteraktivering eller case-undervisning som metode til at nå målet med undervisningen.

Valget af undervisningsmetoder afhænger i den samlede gruppe af interviewpersoner mere af personlighed end af social kontekst. Mange af underviserne taler om deres undervisningsmetode som værende begrundet i lang erfaring med pædagogisk praksis, og at "undervisningsmetoden er stærkt personlig - en intuitiv tilgang, som er bygget op gennem en professionel praksis ". Valg af undervisningsmetoder er således tættere knyttet til underviserens erfaring (gennem egen uddannelse og praktisk-pædagogiske virke) og faget, der undervises i, end til målet med undervisningen.

Som en pendant til det følelsesmæssige element i respondenternes tilgang til forskningen, er det interessant gennem vores analyser af personlighedsdimensionen at observere, hvordan vores respondenter beskriver personlige eller følelsesmæssige relationer mellem underviser og studerende i undervisningen. Det er påfaldende, at det primært kun er undervisere, som varetager interdisciplinariteten selv, der nævner relationer til de studerende: "De studerende skal opleve, at de har det godt - at underviseren er nærværende". "Man skal ikke være en distanceret underviser," og "jeg betragter mine studerende som mine børn". Relationerne, der her bliver beskrevet, er tætte relationer, hvor underviseren i høj grad engagerer sig i de studerendes udvikling og er meget bevidst om (underviser-) rollen som procesfacilitator. Den anden gruppe undervisere nævner ikke relationer mellem underviser og studerende, 
hvilket selvfølgelig ikke er ensbetydende med, at de ikke er bevidste om eller engagerede i de studerendes læreproces. Det står bare ikke helt så centralt som for "solounderviserne".

Analyserne viser således, at i det interdisciplinære undervisningsarbejde er det mere oplagt at have fokus på de studerendes læreproces og selvindsigt, når man som underviser varetager interdisciplinariteten alene, hvorimod faglig viden og anvendelse i højere grad står centralt for den underviser, der skal varetage interdisciplinariteten i samarbejde med andre. Samtidig kan der ikke spores nogen polarisering mellem de to undervisergrupper i valg af metoder til at nå disse forskellige mål. Det kan derfor diskuteres, hvorvidt forskellen i formålet med undervisningen sætter sig spor i gennemførelsen af undervisningen. Endelig er det værd at notere sig, at flertallet af undervisere - uanset "socialt" tilhørsforhold - beskriver solo-undervisningsorganiseringen som det efterstræbelsesværdige - det er simpelthen "sjovere at følge de studerendes processer", mens perler på en snor-organiseringen generelt opleves som en gangbar men noget mekanisk undervisningsstruktur.

\section{Konklusion}

Som udgangspunkt vidste vi, at der blandt forskere er forskellige overvejelser om valideringsprocesser og dermed sandhedskriterier (Donald, 1990). I vores undersøgelse har vi ønsket at sætte fokus på den interdisciplinære tilgang til det akademiske arbejde. Inden for dette felt ser vi, at forskelle med hensyn til forståelse af sandhed kan have en sammenhæng med de sociale relationer i det interdisciplinære samarbejde. De forskere, som arbejder alene med at sammentænke flere discipliner, er mere frie i deres forhold til spørgsmålet om sandhed. Friheden betyder, at de er mere fokuserede i deres metodevalg. De forskere, der arbejder sammen med andre om at sammentænke flere discipliner, ser sandheden som værende forbundet med forhandlinger og med empirisk eller logisk afprøvning. De er mere underlagt nødvendighedens lov og bliver mere pragmatiske i deres metodevalg.

Ser vi på undervisningen, er der en tendens til, at de undervisere, som alene varetager et interdisciplinært forløb, sætter fokus på den studerendes personlige udvikling og ser sig selv som rollemodel og mentor for de studerende. Omvendt lægger de undervisere, som sammen med andre varetager interdisciplinær undervisning, vægt på den faglige udvikling. Her bliver de mere personlige udviklingsperspektiver hos de studerende ikke nævnt.

Alt i alt må man sige, at interdisciplinariteten virker befriende for de akademiske medarbejdere, som forsker og underviser alene. De glæder sig over mulighederne for at udvide egen og andres erkendelse, og de lægger vægt på at kunne påvirke de studerendes udvikling - ikke blot på det faglige men også på det personlige niveau. For de akademiske medarbejdere, som arbejder sammen med kolleger omkring forsk- 
ning og undervisning, ser vi tendenser til, at glæden ved at sammentænke flere discipliner bliver blandet med følelser af begrænsninger og frustrationer. Samarbejdet har sin pris - men det kan være meget berigende, motiverende og kvalificerende, hvis man vil det.

\section{Perspektiver: Hvad betyder dette for den universitetspædagogiske praksis?}

Da universiteterne skal levere forskningsbaseret undervisning, har det en betydning hvilken opfattelse af god forskning/vidensudvikling, der bliver videregivet til de studerende. Det er ganske tankevækkende, at den fremherskende undervisningstilgang, perler på en snor-undervisningen, ikke har fokus på de studerendes udvikling og perspektivering af faget og ikke umiddelbart lader sig associere med personlige relationer i undervisningen mellem underviser og studerende. Konsekvensen bliver, at vi får meget undervisning på interdisciplinære uddannelser, som leder de studerende ind i en disciplin og direkte ud igen, men sjældent rundt $i$ og om et interdisciplinært felt. Underviserne lader det være op til de studerende at finde ud af, hvordan disciplinerne kan forbinde, skabe dialog og gensidigt udvikle hinanden. Resultaterne tyder på, at man især på interdisciplinære uddannelser skal gøre særlig meget ud af at give underviserne mulighed for og ressourcer til at sammentænke undervisning og måske endda til at følge og følge op på hinandens undervisning.

Anne Jensen er lektor $i$ sprogtilegnelse og sprogpædagogik ved Syddansk Universitet, institutleder på IKV samt leder af SDUs Center for Universitetspæedagogik. Hendes opgaver inkluderer, ud over ledelsesopgaverne uddannelsesudvikling, kompetenceudvikling, kvalitetsudvikling mv. Hun er uddannet inden for det humanistiske hovedområde i Fransk, Litteraturvidenskab og Dansk.

Rie Troelsen er lektor i universitetspædagogik ved Syddansk Universitet. Her arbejder hun med undervisnings- og uddannelsesudvikling, efteruddannelse og kompetenceudvikling hos universitetsansatte. Hendes forskningsinteresser centrever sig især om professionaliseringen af universitetsundervisningen/-underviseren. Hun er uddannet inden for det naturvidenskabelige område i Kemi.

Lilli Zeuner er lektor i uddannelsessociologi ved Syddansk Universitet. Hun underviser ved såvel bacheloruddannelsen $i$ interkulturel pædagogik som ved kandidatuddannelsen $i$ pædagogik. Hendes forskning har i de senere år koncentreret sig om gymnasiepædagogik, lærerroller, interdisciplinaritet og unges uddannelsesvalg. Hun er uddannet inden for det samfundsvidenskabelige område i Kultursocio$\log i$.

\section{Referencer}

Archer, M. S. (1988/1996). Culture and agency. The place of culture in social theory. Revised Edition. Cambridge: Cambridge University Press.

Armstrong, F. H. (1980). Faculty development through interdisciplinarity. The Journal of general education, 32 (1), 52-63.

Bloch, C. (2007). Passion og paranoia. Følelser og følelseskultur i Akademia. Odense: Syddansk Universitetsforlag. 
Bourdieu, P. (1979/1984). Distinction. A Social Critique of the Judgement of Taste. London: Routledge \& Kegan Paul.

Brew, A. (2008). Disciplinary and interdisciplinary affiliations of experienced researchers. Higher Education, 56, 423-438.

Camic, C. \& Joas, H. (2004). The Dialogical Turn. New Roles for Sociology in the Postdisciplinary Age. Lanham: Rowman \& Littlefield Publishers.

Cook-Sather, A. \& Shore, E. (2007). Breaking the rule of discipline in interdisciplinarity: Redefining professors, students, and staff as faculty. Journal of Research Practice, 3 (2), Article M15.

Dewey, J. (1916). Democracy and Education. Southern Illinois: University Press.

Donald, J. (1990). University professors' views of knowledge and validation processes. Journal of Educational Psychology, 82 (2), 242-249.

Finkenthal, M. (2001). Interdisciplinarity. New York: Peter Lang.

Francks, D., Dale, P., Hindmarsh, R., Fellows, C., Buckridge, M., \& Cybinski, P. (2007). Interdisciplinary foundations: reflecting on interdisciplinarity and three decades of teaching and research at Griffith University, Australia. Studies in Higher Education, 32 (2), 167-185.

Fry, G. L. A. (2001). Multifunctional landscapes - towards transdisciplinary research. Landscape and Urban Planning, 57, 159-168.

Gibbons, M., Limoges, C., Nowotny, H., Schwartzman, S., Scott, P., \& Trow, M. (1994). The New Production of Knowledge. The Dynamics of Science and Research in Contemporary Societies. London: Sage.

Habermas, J. (1984-1987 /1991). The Theory of Communicative Action. Vol. 1-2. Cambridge: Polity.

Kline, S. J. (1995). Conceptual Foundations for Multidisciplinary Thinking. Stanford: Stanford University Press.

Lacutta, L. R. (2002). Learning interdisciplinarity. Sociocultural perspectives on academic work. The Journal of Higher Education, 73 (6), 711-739.

Moran, J. (2002). Interdisciplinarity. London: Routledge.

Nowotny, H., Scott, P., \& Gibbons, M. (2001). Rethinking Science. Knowledge and the Public in an Age of Uncertainty. Cambridge: Polity.

Trigwell, K. (2005). Teaching-research relations, cross-disciplinary collegiality and student learning. Higher Education, 49, 235-254.

Weber, M. (1904/49). "Objectivity" in social science and social policy. I: The Methodology of the Social Sciences. New York: Free Press.

Wuthnow, R. (1989). Communities of Discourse. Ideology and Social Structure in the Reformation, the Enlightenment, and European Socialism. Cambridge, Massachusetts: Harvard University Press.

Youngblood, D. (2007). Interdisciplinary studies and the bridging disciplines: A matter of process. Journal of Research Practice, 3 (2), Article M18. 